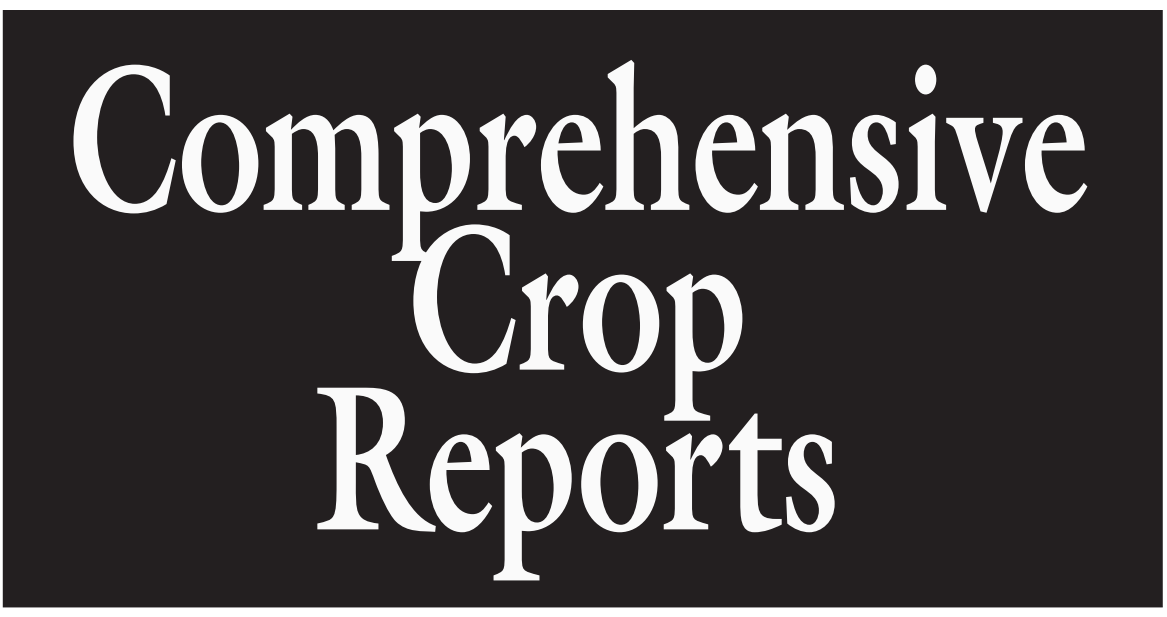

\title{
Fire Flash: An Exotic Ornamental Foliage Plant
}

\author{
Jianjun Chen ${ }^{1}$, Dennis B. McConnell ${ }^{2}$, Richard J. Henny ${ }^{3}$, \\ Kelly Everitt ${ }^{4}$, and Russell D. Caldwell ${ }^{5}$
}

Additional Index words. Chlorophytum amaniense, foliage plant production, houseplants, interior plantscapes, low light tolerance, new crop

\begin{abstract}
SumMARY. Fire flash (Chlorophytum amaniense), a member of Liliaceae, is attracting considerable attention in the foliage plant industry as a new addition for interior plantscaping. Coral-colored petioles and midribs contrasting with dark green leaves make it a sought after specimen. Originally collected from rainforests of eastern Africa in 1902, it has remained largely obscure for a century. Recently, studies on fire flash's propagation, production, and interiorscape performance have been completed. This report presents relevant botanical information and the results of our 4-year evaluation of this plant. Fire flash can be propagated through seed, division, or tissue culture and produced as a potted foliage plant under light levels from 114 to $228 \mu \mathrm{mol} \cdot \mathrm{m}^{-2} \cdot \mathrm{s}^{-1}$ and temperatures from 18 to $32{ }^{\circ} \mathrm{C}$. Finished plants after being placed in building interiors are able to maintain their aesthetic appearances under a light level as low as $8 \mu \mathrm{mol} \cdot \mathrm{m}^{-2} \cdot \mathrm{s}^{-1}$ for $8 \mathrm{months}$ or longer.
\end{abstract}

\section{Origin and history}

$\mathrm{T}$ The genus Chlorophytum belongs to Liliaceae and encompasses about 215 species chiefly native to tropical and subtropical Africa and Asia (Huxley, 1994). Most species are evergreen perennials with rhizomatous roots either short and fibrous or thick and translucent. Some species found in the wild are important to local cultures, such as C. borivilianum in India, commonly known as "safed musli," whose storage roots are reputed to have aphrodisiac properties. The dried fasciculated roots form an important ingredient of herbal tonics prescribed in the Ayurvedic system of medicine in India (Kirtikar and Basu, 1975; Bordia et al., 1995). The species that the ornamental plant industry is most familiar with is C. comosum or spider plant. Cultivars have either variegated or solid green foliage, produce proliferous stolons, and have been widely used as hanging baskets for interior decoration (Griffith, 1998).

Another species of Chlorophytum was introduced into the foliage plant industry in the late 1990s. Commonly called fire flash, it has broad leaves and coral-colored midribs and petioles. Other names, including mandarin plant and tangerine, have also been given. As there was no description in either Exotica (Graf, 1985) or Tropica (Graf, 1992), fire flash was initially considered to be $C$. orchidantheroids (Chen et al., 2002; Henny and Chen, 2003). However, its unique colored petioles and midribs within the genus Chlorophytum classify fire flash as C. amaniense. This species is native to the rain forests of eastern Africa; the originally described specimens were collected in 1902 in ravines near the village of Amani in the Usambara Mountains of Tanzania (Dress, 1961). It may have been collected and introduced into botanical conservatories shortly after its discovery since Engler (1904) described it. Dress (1961) reported that it was grown in German botanical gardens before 1910. However, the ornamental value of and production techniques for fire flash remained largely obscure over the last 100 years, and only three known references have briefly mentioned it (Dress, 1961; Jones and Smith, 1967; Somashekar, 1987). Since its initial introduction into Florida's nursery industry in the late 1990s, we have been evaluating fire flash. This is the first report that presents relevant botanical information concerning $C$. amaniense, methods of its propagation and production, and results of its interior performance to the ornamental plant industry.

\section{Botanical description}

Fire flash is a rhizomatous herb with lanceolate leaves borne on a short, stout stem in a rosette arrangement

\begin{abstract}
This research was supported by the Florida Agricultural Experiment Station and approved for publication as journal series R-10558. The authors appreciate AgriStarts, Inc. Apopka, Fla., for providing fire flash liners used in this study.

${ }^{1}$ Associate Professor and corresponding author, Dept. of Environmental Horticulture and Mid-Florida Research and Education Center, IFAS, University of Florida, 2725 Binion Road, Apopka, FL 32703.

${ }^{2}$ Professor, Dept. of Environmental Horticulture, IFAS, University of Florida, 1519 Fifield Hall, P.O. Box 110670, Gainesville, FL 32611.

${ }^{3}$ Professor, Dept. of Environmental Horticulture and Mid-Florida Research and Education Center, IFAS, University of Florida, 2725 Binion Road, Apopka, FL 32703

${ }^{4}$ Research Assistant and ${ }^{5}$ Biological Scientist, Mid-Florida Research and Education Center, IFAS, University of Florida, 2725 Binion Road, Apopka, FL 32703.
\end{abstract}

\begin{tabular}{llll}
\hline $\begin{array}{l}\text { Units } \\
\begin{array}{l}\text { To convert U.S. to SI, } \\
\text { multiply by }\end{array}\end{array}$ & U.S. unit & SI unit & $\begin{array}{l}\text { To convert SI to U.S., } \\
\text { multiply by }\end{array}$ \\
\hline 2.5400 & inch $(\mathrm{es})$ & $\mathrm{cm}$ & 0.3937 \\
25.4000 & inch $(\mathrm{es})$ & $\mathrm{mm}$ & 0.0394 \\
6.4516 & inch & $\mathrm{cm}^{2}$ & 0.1550 \\
0.0160 & $\mathrm{lb} / \mathrm{ft}^{3}$ & $\mathrm{~g} \cdot \mathrm{cm}^{-3}$ & 62.4274 \\
0.0010 & $\mu \mathrm{mho} / \mathrm{cm}$ & $\mathrm{mS} \cdot \mathrm{cm}^{-1}$ & 1.000 \\
28.3495 & $\mathrm{oz}$ & $\mathrm{g}$ & 0.0353 \\
1 & $\mathrm{ppm}$ & $\mathrm{mg} \cdot \mathrm{L}^{-1}$ & 1 \\
$\left({ }^{\circ} \mathrm{F}-32\right) \div 1.8$ & ${ }^{\circ} \mathrm{F}$ & ${ }^{\circ} \mathrm{C}$ & $\left(1.8 \times{ }^{\circ} \mathrm{C}\right)+32$
\end{tabular}


(Fig. 1A). Glossy leaf blades are 20 to $30 \mathrm{~cm}$ long and 7 to $8 \mathrm{~cm}$ wide, with 20 to 26 veins that taper at the base to channeled petioles that are 5 to $15 \mathrm{~cm}$ long and 4 to $8 \mathrm{~mm}$ broad. Leaves are dark green, but petioles and midribs are a unique coral color. In contrast to thick roots of spider plant (Fig. 1B-a), its rhizomes have nearly oval tubers in the middle of roots (Fig. lB-b). Emerging inflorescences trigger axillary shoot development. In addition, basal shoots appear when plants are close to maturity or grown under well-fertilized conditions. A finished plant generally has 15 to 30 leaves with heights of 30 to $50 \mathrm{~cm}$ and widths of 40 to $60 \mathrm{~cm}$.

The inflorescence appears only on mature plants beginning in January. It is an erect panicle, 4 to $14 \mathrm{~cm}$ tall and made up of racemose branches that bear small white flowers overtopped by narrow subtending bracts (Fig. lC-b). The oblong capsules are 10 to $14 \mathrm{~mm}$ long and 7 to $9 \mathrm{~mm}$ wide. Like spider plants (Fig. 1C-a), flowers of fire flash are rotate; the six tepals remain separate to the base and do not twist upon withering (Fig. 1Cb). The six stamens carry inwardly dehiscent anthers; the pistil consists of a capitate stigma, filiform style, and an ovoid, three-carpellary ovary with several ovules in each carpel. A deep three-lobbed capsule bears seeds, which dehisces loculicidally from May and June. The seeds are small, black, discoid, somewhat compressed but not flat (Fig. 2A) and have a dry seed count of 1298 seeds $/ \mathrm{g}$.

Fire flash is a diploid species $(2 n$ $=14$ ) with a base chromosome number of $x=7$ (Jones and Smith, 1967), which contrasts to spider plant that is a tetraploid species $(2 n=28)$. Fire flash pollen is fertile, and 15 to 25 viable seeds can be harvested from an isolated flower, suggesting it is a self-pollinated species. However, a higher frequency of meiotic abnormalities, such as univalents, fragments, and bridged chromosomes, occurs when flower buds are subjected to treatments of different concentrations of dye industry waste water, which often contains high levels of heavy metals (Somashekar, 1987). These abnormalities can cause pollen sterility, thus reducing seed production. No additional cultivars are known from this species and no breeding programs to enhance its aesthetic value have been reported.
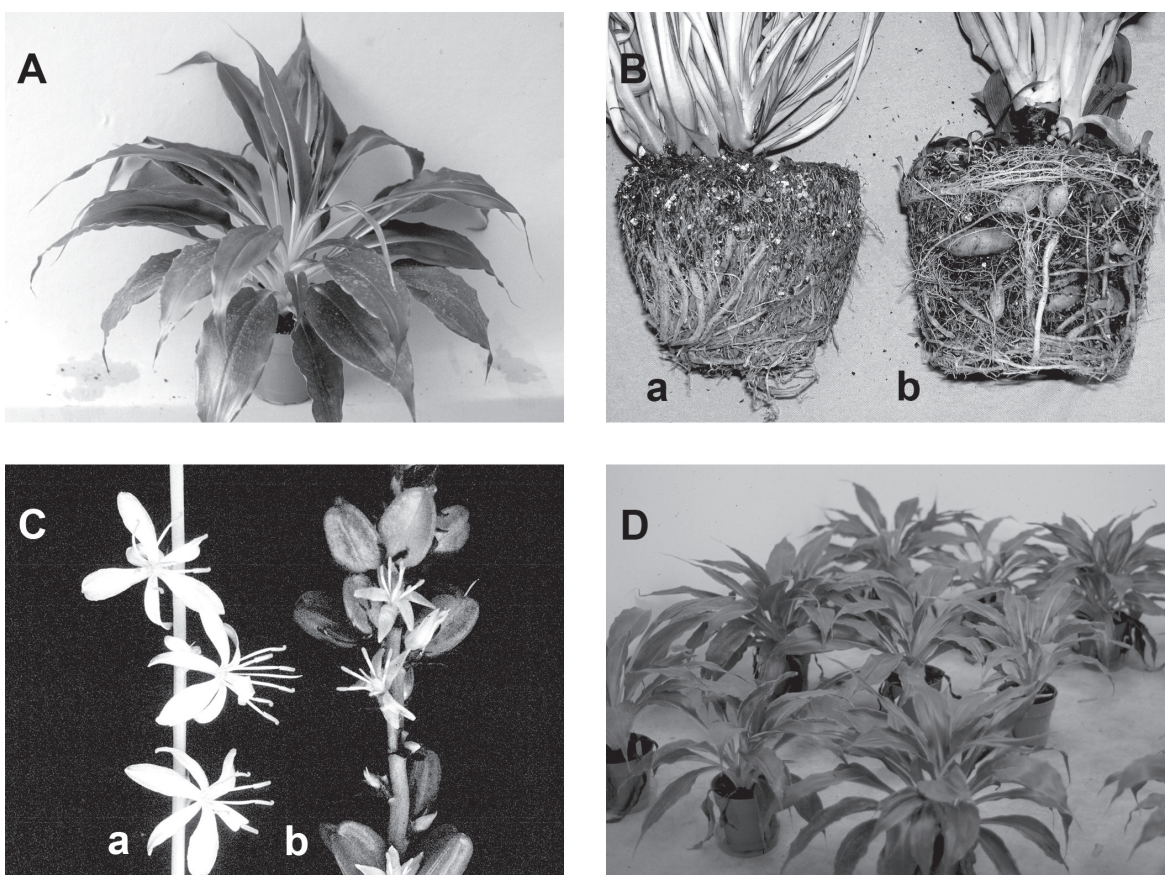

Fig. 1. (A) A finished fire flash grown in a 15 -cm-diameter (5.9 inches) container; (B) thick roots of spider plants (a) contrasting to roots with tube-like structure of fire flash (b); (C) flowers of spider plant (a) and flowers and seed pods of fire flash (b); (D) fire flash in simulated interior conditions [light intensity of $8 \mu \mathrm{mol} \cdot \mathrm{m}^{-2} \cdot \mathrm{s}^{-1}$, temperature of $24^{\circ} \mathrm{C}$, and relative humidity of $50 \%$ to $60 \%$ ] for 1 year.
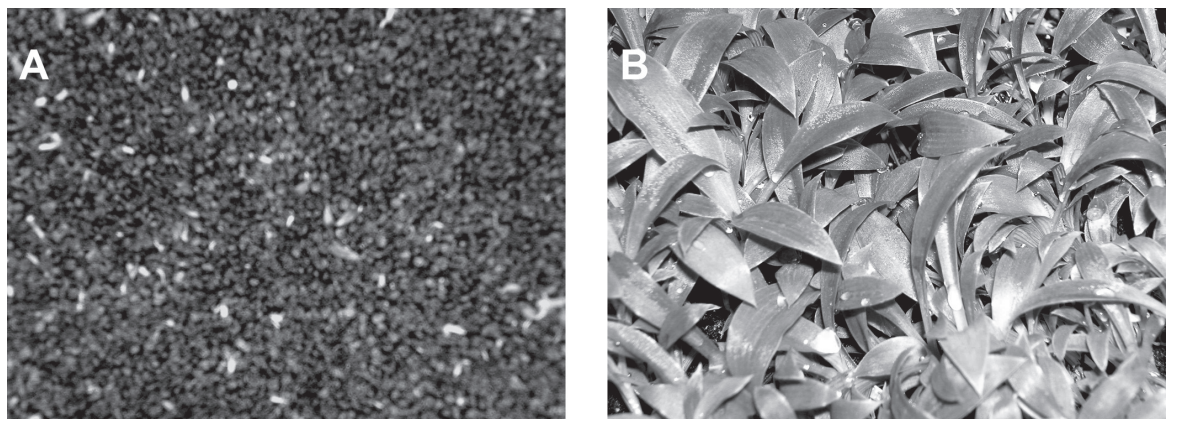

Fig. 2. (A) Seeds and (B) germinated seedlings of fire flash.

\section{Ornamental value}

The uniqueness of this plant is the colored foliage. Bright coral petioles and midribs contrast with deep green leaves, making it an exotic-appearing and exciting new plant. Although there are 215 species of Chlorophytum, fire flash bears little resemblance to the others. It has broad lanceolate leaves, no stolons, and thus no plantlets produced as propagalues. Fire flash is the only species in the genus with such a distinct coloration. In fact, this coloration is rare among almost all cultivated foliage plant species. As interior plantscapers and homeowners are constantly looking for new and unusual plants, fire flash has quickly gained popularity as an exotic plant in the foliage plant industry.

Another important characteristic of fire flash is its ability to tolerate low light intensity typical of building interiors. Our study shows that fire flash can adapt well to interior conditions under a light level of $8 \mathrm{\mu mol} \cdot \mathrm{m}^{-2} \cdot \mathrm{s}^{-1}$ for 8 months or longer (Fig. ID) (J. Chen et al., unpublished data). New leaves are produced while old leaves slowly senesce indoors. Leaf areas of the new leaves are generally smaller, 80 to $115 \mathrm{~cm}^{2}$, than those ranging from 120 to $170 \mathrm{~cm}^{2}$ grown in the shaded greenhouses. No growth disorder, disease, or pest problems occurred over the evaluation period. Leaves were dark green and petioles and midribs 
remained coral colored; thus, the overall form and appearance remained attractive. The plants were able to flower and produce viable seeds under these interior low light conditions. Since the ability to adapt to interior low light environments and maintain an aesthetic appearance for a prolonged time is one of the most important traits in determining the ornamental value of a foliage plant (Henny and Chen, 2003), the performance of fire flash has demonstrated its potential as an important interiorscaping plant.

Apart from the ornamental value, fire flash may contain antitumour steroidal saponins as do other species of Chlorophytum. These compounds have been isolated from $C$. arundinaceum (Tandon and Shukla, 1997), C. borivilianum (Seth et al., 1991), C. comosum (Mimaki et al., 1996), and $C$. malayense (Qiu et al., 2000) and have shown cytotoxicity in vitro against several human cancer cell lines. The potential pharmaceutical value of fire flash remains to be determined.

\section{Propagation}

Fire flash can be propagated through seed, division, and tissue culture. Seed is sowed either individually on the surface of media-filled cell of plastic trays that have 72 plugs or broadcasted in seedling flats (Fig. 2B). Seedlings that germinate from cells are plugs, whereas seedlings grown from flats have to be removed and manually transplanted into containers. The medium should be a sphagnum peat, perlite, and vermiculite mix (see below for potting media). Seeds used for germination can be either fresh or stored for up to 1 year under 20 to $24{ }^{\circ} \mathrm{C}$. Our seed germination study showed that fresh seeds germinated in 3 weeks, whereas seeds stored for 1 year germinated within $14 \mathrm{~d}$ in a shade greenhouse with temperature ranging from 21 to $30^{\circ} \mathrm{C}$ and a light intensity of $228 \mu \mathrm{mol} \cdot \mathrm{m}^{-2} \cdot \mathrm{s}^{-1}(\mathrm{~J}$. Chen et al., unpublished data). It takes about 3 months for seedlings to be ready for transplanting. Division is accomplished by separating basal shoots with roots from the mother plants and planting the basal shoots singly in containers. Tissue culture is becoming the main method of propagating fire flash as it provides uniform liners year-round $(\mathrm{R}$. E. Strode, personal communication). A single plant liner is recommended for containerized production.

\section{Production}

Seedlings or liners that have four to five leaves can be transplanted in 10-, 15-, and 20-cm-diameter containers. Division resultant basal shoots are usually planted either in $15-$ or $20-\mathrm{cm}$ containers filled with soilless media. Fire flash requires growing under heavy shade environments.

Potting mix. Most commercial soilless potting media that have $40 \%$ to $50 \%$ sphagnum peat with balanced volumes of pine bark and vermiculite are adequate for fire flash production. The media should have a bulk density of 0.1 to $0.5 \mathrm{lb} / \mathrm{ft}^{3}$ based on dry weight, container capacity of $20 \%$ to $60 \%$ by volume, total porosity of $50 \%$ to $75 \%$, moisture content of $50 \%$ to $75 \%$, and air space of $10 \%$ to $20 \%$ (Chen et al., $2005)$. The electrical conductivity (EC) of the media should range from 1000 to $2000 \mu \mathrm{mhos} / \mathrm{cm}$ when the bulk solution is extracted using the pourthrough method (Yeager et al., 1983) and a $\mathrm{pH}$ of 5.5 to 6.5 . Supplements of superphosphate into potting media should be avoided because it carries fluoride that may cause tipburn in production of Chlorophytum (Conover and Poole, 1981).

Light. Because its natural habitat
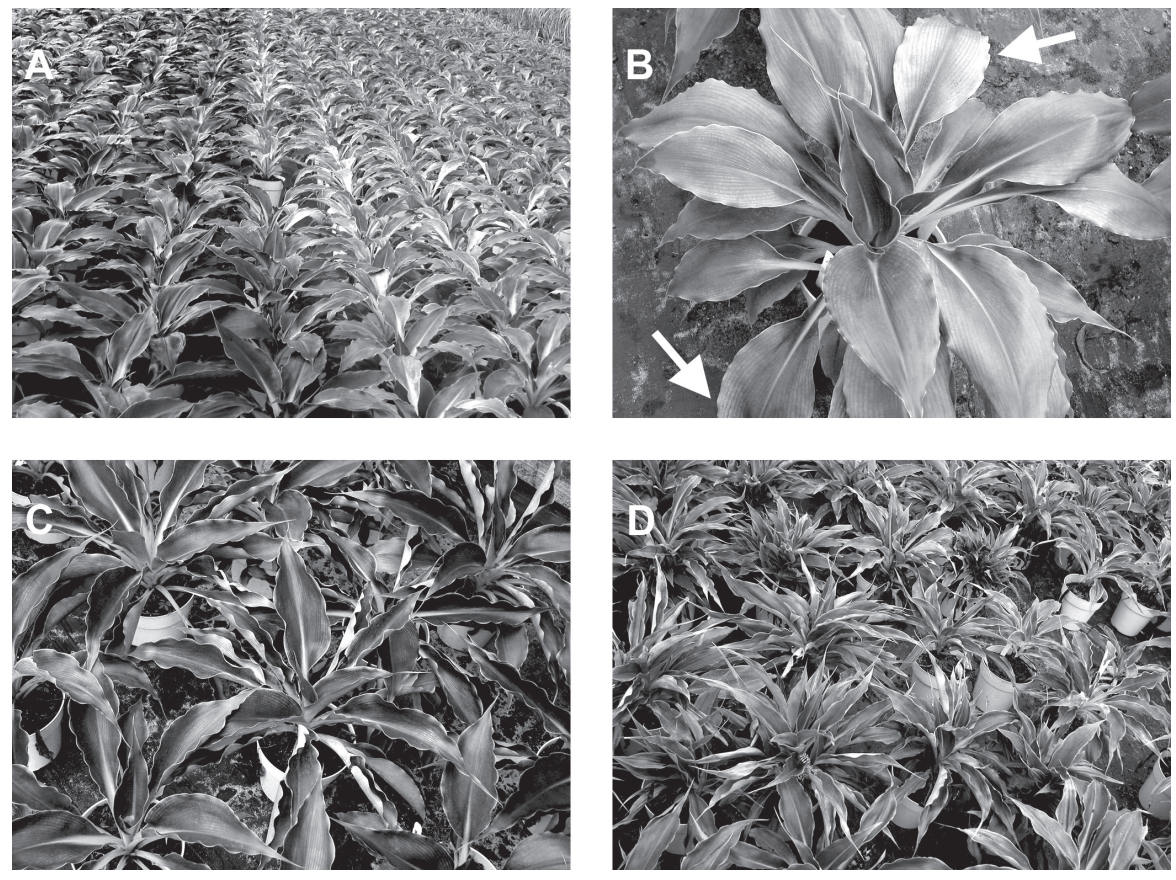

Fig. 3. (A) Foliar color differences when fire flash plants were exposed to light levels of $190 \mu \mathrm{mol} \cdot \mathrm{m}^{-2} \cdot \mathrm{s}^{-1}$ (left) and $475 \mu \mathrm{mol} \cdot \mathrm{m}^{-2} \cdot \mathrm{s}^{-1}$ (right); (B) leaf chlorosis and necrotic lesions (indicated by arrows) caused by high production light intensity $\left(475 \mu \mathrm{mol} \cdot \mathrm{m}^{-2} \cdot \mathrm{s}^{-1}\right)$; (C) fire flash with cupped leaves due to drought stress in production; and (D) fire flash with multiple narrow leaved shoots produced when tissue cultured liners with more than one shoot were used. 
$\mathrm{mmol} \cdot \mathrm{m}^{-2} \cdot \mathrm{s}^{-1}$ water (J. Chen et al., unpublished data). Thus, media should be kept moist but not overwatered. A slight drought not only reduces plant growth, but also causes cupped leaves (Fig. 3C). Either drip or subirrigation is preferred as overhead irrigation leaves water residues on glossy leaves, which affect the plant's appearance.

Controlled-release fertilizers, such as Osmocote 18-6-12 with micronutrients $(18.0 \mathrm{~N}-2.6 \mathrm{P}-10.0 \mathrm{~K}$, 8-9 months; Scotts Co., Marysville, Ohio), can be either surface applied or incorporated at 4, 6, and $8 \mathrm{~g}$ per 10-, 15-, and 20-cm-diameter containers, respectively. When a water-soluble fertilizer with $\mathrm{N}-\mathrm{P}_{2} \mathrm{O}_{5}-\mathrm{K}_{2} \mathrm{O}$ at 3-1-2 ratio $(3 \mathrm{~N}-0.4 \mathrm{P}-1.7 \mathrm{~K})$ and containing micronutrients is used, nitrogen at 200 $\mathrm{mg} \mathrm{L}^{-1}$ for drip-irrigated plants and 100 to $150 \mathrm{mg} \cdot \mathrm{L}^{-1}$ for sub-irrigated plants is adequate. Growers should monitor EC levels of container media regularly using the pour-through method (Yeager et al., 1983). If EC readings are below $1000 \mu \mathrm{mhos} / \mathrm{cm}$, additional fertilization is needed; whereas if $\mathrm{EC}$ readings are higher than $3000 \mu \mathrm{mhos} / \mathrm{cm}$, growers should reduce either fertilizer frequency or the amount applied. Fire flash generally attains marketable sizes in 3,4 , and 5 months for 10-, 15-, and 20-cm-diameter containers, respectively, after transplanting.

InSECTS AND DISEASES. To date, no specific pests or diseases have been reported for fire flash. However, there is a potential for root rot if plants are overwatered. Unless absolutely necessary, do not spray chemicals, including insecticides, bactericides, or fungicides, on leaves to avoid any potential phytotoxicity. Always test chemicals on a few plants before spraying the entire crop.

COMMON PRODUCTION PROBLEMS. The most common problem encountered in fire flash production is leaf chlorosis followed by necrosis (Fig. 3A-B). Excessive light intensity, poor nutrient management, and/or chemical phytotoxicity are blamed for this problem. Avoiding high production light intensity is the key; do not produce this plant under a light level higher than 228 $\mu \mathrm{mol} \cdot \mathrm{m}^{-2} \cdot \mathrm{s}^{-1}$. In addition, if plants are not used for seed production, remove the inflorescence after it appears. Allowing inflorescence development will compete for nutrients, delay production time by about 1 month, and/or cause leaf chlorosis. Additionally, the dried up inflorescences will affect the overall appearance of the plant.

Occasionally, crowded, small leaved, and multiple shoot plants occur during production (Fig 3D). These plants have little ornamental value and should be rogued. They originate from tissue culture liners that either clumped or have multiple shoots. The use of single shoot liners will eliminate this problem.

\section{Transportation and interior use}

Since fire flash is initially produced under rather low light intensity, additional light acclimatization is not necessary (Chen et al., 2005). Finished plants are groomed and packed by inserting individual containerized plants into sleeves and placing sleeved plants in appropriate boxes for shipping. The sleeve is necessary as leaves of this plant are fragile. Fire flash should be transported in refrigerated carriers at a temperature of 16 to $18{ }^{\circ} \mathrm{C}$ for long distance shipping. Chilling injury may occur if shipping temperature drops below $10{ }^{\circ} \mathrm{C}$ for more than $12 \mathrm{~h}$.

Once arriving at their final destination after shipping, plants should be placed in interior light levels of 8 umol m $\mathrm{m}^{-2} \cdot \mathrm{s}^{-1}$. Plants produced in $10-$ and $15-\mathrm{cm}$-diameter containers can be placed on office desks or table tops, but $20-\mathrm{cm}$ containers are best used as floor plants. Occasional grooming of the plant is needed to remove senesced leaves and inflorescences that develop. Plants should not be fertilized unless EC readings are below $1000 \mu \mathrm{mhos} /$ $\mathrm{cm}$. Media should be kept slightly moist in interior conditions. Temperatures of 20 to $24^{\circ} \mathrm{C}$ are most appropriate.

\section{Conclusion}

Fire flash is becoming a popular foliage plant and interiorscape specimen. Its unusual color, low light tolerance, and easy care add to its unique appeal. It is easy to imagine this fine plant in hotel conservatories and brightening up dark corners. Perhaps fire flash could be displayed in box planters to add flashes of color to offices. They would be beautiful in a home surrounded by lush ferns, giving the effect of fire warming an interiorscape. Its versatility is an enormous asset for this exotic plant.

\section{Literature cited}

Bordia, P.C., A. Joshi, and M.M. Simlot. 1995. Safed musli, p. 429-451. In: K.L. Chadha and
R. Gupta (eds.). Medicinal and aromatic plants. Malhotra Publ., New Delhi.

Chen, J., R.J. Henny, and D.B. McConnell. 2002. Development of new foliage plant cultivars, p. 446-452. In: J. Janick and A. Whipkey (eds.). Trends in new crops and new uses. ASHS Press, Alexandria, Va.

Chen, J., D.B. McConnell, D.J. Norman, and R.J. Henny. 2005. The foliage plant industry. Hort. Rev. 31:47-112.

Conover, C.A. and R.T. Poole. 1981. Fluoride analysis of materials commonly available as nutritional soil amendments. Univ. of Florida, Inst. of Food and Agr. Sci., Agr. Res. Ctr.-Apopka, Res. Rpt. RH-81-12.

Dress, W. 1961. Chlorophytum (Liliaceae) in cultivation. Baileya 9:29-50.

Engler, A. 1904. Liliaceae Chlorophytum amaniense. Botanische Jahrbucher 34:157.

Graf, A.B. 1985. Exotica, series 4 international. 12th ed. Roehrs, East Rutherford, N.J.

Graf, A.B. 1992. Tropica. 4th ed. Roehrs, East Rutherford, N.J.

Griffith, L.P. 1998. Tropical foliage plants: A grower's guide. Ball Publ., Batavia, Ill.

Henny, R.J. and J. Chen. 2003. Foliage plant cultivar development. Plant Breeding Rev. 23:245-290.

Huxley, A. 1994. The new Royal Horticultural Society dictionary of gardening. Macmillan, London.

Jones, K. and J.B. Smith. 1967. The chromosomes of the Liliaceae: I. The karyotypes of twenty-five tropical species. Kew Bul. $21: 31-38$.

Kirtikar, K.R. and B.D. Basu. 1975. Indian medicinal plants. Vol. IV, M/S Periodical Experts, New Delhi.

Mimaki, Y., T. Kanmoto, Y. Sashida, A. Nishino, Y. Satomi, and H. Nishino. 1996. Steroidal saponins from the underground parts of Chlorophytum comosum and their inhibitory activity on tumor promoter-induced phospholipids metabolism of HeLa cells. Phytochemistry 41:1405-1410.

Qiu, S., X. Li, Y. Xiong, Y. Dong, H. Chai, N.R. Farnsworth, J.M. Pezzuto, and H.H. Fong. 2000 . Isolation and characterization of cytotoxic saponin chloromaloside A from Chlorophytum malayense. Planta Medica 66:587-590.

Seth, P., M.K. Sharma, and M.M. Simlot. 1991. Saponins in Chlorophytum species. Proc. India Soc. Biol. Chem. Biotechnol. 28:1-20.

Somashekar, R.K. 1987. Meiotic abnormalities induced by dye industry waste water in Chlorophytum amaniense Engler. Cytologia 52:647-652.

Tandon, M. and Y.N. Shukla. 1997. Arundinoside A-a new acylated glucoside from Chlorophytum arundinaceum. Indian J. Chem. 35B:988-999.

Yeager, T.H., R.D. Wright, and S.J. Donohue 1983. Comparison of pour-through and saturated pine bark extract $\mathrm{N}, \mathrm{P}, \mathrm{K}$, and $\mathrm{pH}$ levels. J. Amer. Soc. Hort. Sci. 108:112-114. 